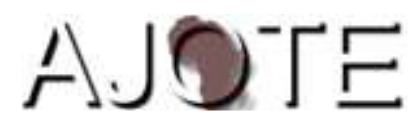

African Journal of Teacher Education

ISSN 1916-7822. A Journal of Spread Corporation

Volume $8 \quad 2019 \quad$ Pages 361-379

\title{
Effect of Self-Regulated Learning Strategy on students' achievement in Basic Science in Makurdi Local Government, Benue State, Nigeria
}

\author{
Christy M. Jirgba, (Ph.D.) \\ Department of Science Education, Federal University of Agriculture, Makurdi \\ Email-mbayagh@gmail.com \\ and \\ Joy Iember Bur \\ Department of Geography, Benue State University, Makurdi
}

\begin{abstract}
This study examined the effects of self-regulated learning instructional strategy on students' achievement in basic science among Upper Basic 2 in Makurdi Local Government Area of Benue State. The study employed non-equivalent group pre-test-post-test quasi experimental design. The population of the study was 638 upper basic school levels. The sample for this study was 128 students from six co-educational schools within Makurdi Local Government Area of Benue State. Two research questions and two hypotheses guided the study. The instrument used for data collection was Basic Science Achievement Test (BSAT) and was trial tested using KuderRichardson $(K-R, 20)$ formula to determine the reliability coefficient of BSAT which was found to be 0.99. Descriptive statistics of means and standard deviation were used to answer all the research questions and inferential statistics of Analysis of Covariance (ANCOVA) was used to test all the hypotheses at 0.05 significant level. The results of the study showed that demonstration method enhanced students' achievement in basic science better than selfregulated strategy. There is no significant difference between the mean achievement score of students taught basic science using self-regulated learning strategy and those taught using demonstration method. There was no significant difference between the mean achievement scores of male and female students taught basic science using self-regulate learning strategy. Basic science Teachers should not only use demonstration method to teach but also allow the student to actively participate in the learning. This can foster confidence in the students and enhance better achievement in basic science.
\end{abstract}


Christy M. Jirgba and Joy Iember Bur

Key words: Self-Regulated Learning; basic science achievement; demonstration method; teaching science.

\section{Introduction}

Nations all over the world, Nigeria inclusive, are striving to develop technologically and scientifically (Adejoh, Amali \& Omaga, 2013). This is only possible with good teaching and learning of science at the secondary school level. Ali (2004) observed that nations that are deemed to be developed and largely considered as civilized have achieved the status through purposeful and strategic scientific education of their citizen.

Relatively, science educators have received national emphasis on the country's bid to achieve indigenous technological and industrial development through improved methodology, National Policy of Education (FRN, 2004). As a result, national, state and private workshops and seminars have given rise to the development of science curriculum projects, such as the Nigerian Primary Science Project (NPSP), the Nigerian Integrated Science Project (NISP) and the Nigerian Secondary School Science Project (NSSSP). Though, these projects were developed more than two decades ago, they seem to have made appreciable impact on the teaching of science subjects in Nigeria. These have not only created a new awareness of science but have also indicated the need for a radical departure from or modification of such conventional methods of teaching sciences such as inquiry methods modified to guided inquiry method. Basic Science educators are also in this quest, since there is dire need of more effective methods of teaching and learning of science.

In view of the importance of science to the national development, science education curriculum is developed at various levels of education in Nigeria. The science education course at the Basic Education level include basic Science and technology at lower and middle Basic Education(primary1-6), Basic science at upper Basic Education(Junior Secondary School(Upper basic1-3). At the senior secondary school level, the subjects include Biology, Chemistry and Physics, while at the tertiary education level, the following courses are available; Biology education, physic education chemistry education and integrated science among others, Nigerian Educational Research and Development Council (NERDC, 2007).

Basic science and technology recently introduced is new in Nigerian schools, though the curriculum is a further enhancement of that of integrated science. Basic science stresses to beginners the general principles which run through the entire world of science. In effect, teachers who are trained to teach basic science must move away from discriminatory attitude towards any 
Effect of Self-Regulated Learning Strategy on students' achievement in Basic Science in Makurdi Local Government, Benue State, Nigeria.

of the sciences. This means that basic science teachers must be competent in the subject matter so as to eliminate the boundaries and repetition from various sciences such as (biology, chemistry, and physics). The objectives of basic science curriculum include developing students interest in science and technology; enabling students acquire basic knowledge and skills in science and technology; enabling students to apply the scientific and technological knowledge and skills to meet societal needs; enabling students to take advantage of the numerous career opportunities offered by science and technology; and enabling learners become prepared for further studies in science and technology, Nigerian Educational Research and Development Council (NERDC,2007).

Basic science is the foundation of all sciences and those who pass it with a credit pass at Basic Education Certificate Examination/ Junior School Certificate Examination (BECE or JSCE) are qualified to read sciences at the Senior Secondary School level. This prepares them to advance to other higher and specific courses in science and technology at the tertiary institutions in Nigeria or abroad.

Realizing the importance of Basic Science in the life of a nation and her citizenry, Nigeria has made repeated efforts to reform its secondary school science education policy. This has culminated in the changes from Integrated Science at lower school level to the current Basic Science with a view to developing a curriculum that will satisfactorily meet the needs of Nigerians. The result has been the encouragement of the use of methods and strategy of instruction that are activity based to improve students' achievement in Basic Science.

Despite the relevance of basic science as a foundation course for the sciences and national development, research report by Okebukola (2005), Ajagun(2006) and Adejoh (2012) working separately have lamented the poor performance of science students in Nigeria. According to Achor and Kalu (2014), the achievement of students in sciences in Nigeria has remained consistently poor. In-fact, a survey of the achievement in Upper Basic School (UBS) Basic science and technology in Nigeria over the years reveals a discernible decline. This phenomenon has remained a source of concern to science educators and specifically Basic Science experts (Okeke, 2007).

Anekwe (2008) attributed the problem to inappropriate teaching strategies and nonavailability of necessary facilities for the teaching of sciences among other things, in addition to students' socio-economic background and intelligence. As a result, many students have failed to advance in science at the senior secondary school due to their poor performance in the Basic 
Science subject at the Basic Education Certificate Examination (BECE) or Junior School Certificate Examination (JSCE). Those who scale through into the Senior Secondary Science class perform poorly at their Senior School Certificate Examination (SSCE) examinations due to their poor foundation at the Basic school level. This may occur as a result of inappropriate use of strategies by science teachers (Anekwe, 2008).

The implementation of the National Policy on Education (FRN,2013) ought to have helped reduce this failure trend. Several factors such as curricular, implementation, lack of provision of instructional materials and lack of man power account for the decline in performance. Unfortunately, the trend appears to have continued as indicated by the reports from Benue State Examination Board (BSEB) Makurdi from 2008-2014. The rate at which students pass Basic Science and Mathematics is low compared to other subjects like Arts and Social studies, Creative art, PHE.

The result of BECE has shown that, students' achievement has persistently remained below 50 percent with the implication that less than half of all students who sat for BECE/JSCE in basic science from 2008 to 2014 failed to obtain the prerequisite grades to pursue scienceoriented career at the higher educational level. This issue of students' underachievement in basic science has been persistently associated with the kind of instructional methods employed by the teachers and may also be due to the difficulty of some science concepts like the human systems and difficulty of some aspects of physics related content in basic science.

On the other hand, Nwosu, (2007), Okeke, (2008) and Azuka (2009), have put the blame for the poor performance in basic science in schools on the classroom teacher: teacher's professional training in school and the method of teaching employed. By and large, evidence of their research findings and day-to-day events appear to lay weight to the foregoing claims that teachers are responsible for the under-achievement in science education. Here reference is often made to the teaching methodology used. Nwosu (2007) pointed out that using the conventional teaching method such as demonstration, lecture, and discussion methods, the teacher talks most of the time while the students listen passively and watch as the teacher demonstrates and reads about the content. This makes the classroom teaching environment teacher dominated, textbook bound, and examination oriented; an environment that lacks the recognition of the need for the development of science process skills in the students. Science teaching must be done through appropriate strategy which fosters understanding for applicability. Good quality teaching gives rise to functional learning (Jirgba, 2008). 
Effect of Self-Regulated Learning Strategy on students' achievement in Basic Science in Makurdi Local Government, Benue State, Nigeria.

Studies by Zimmerman (2005), O’Donnell (2006), Poellhuber, Chiominne and Karsenti (2008) and Samuelson (2010) reveal that learners' understanding of science concepts is often inadequate or erroneous due to poor teaching methodology. The result is that students lack a grasp of the concepts, and they compartmentalize scientific ideas in a process as an outcome of rote learning. This, the researchers noted as a contributory factor in the poor achievement of students in science examination. Achor, Imoko and Uloko (2009) have asserted that methods of science instruction including the activity-based strategies seem to be ineffective in terms of students' achievements and require some modifications.

In agreement with these assertions, Adejoh, (2009) and Samba and Eriba (2012) have researched into method combination and modifications that can bring about effective teaching and learning of Basic Science which is the foundation of all sciences at the higher levels. The researchers observed and from literature that self-learning and as pedagogical strategy are usually not introduced to students of Basic Science at the Upper basic School classes as the actual teaching method in Makurdi and Benue State at large.

Self-regulatory strategy of cognitive behaviour is considered an important aspect of students learning and academic performance in the classroom context. It includes students' metacognitive strategies for planning, monitoring, modifying their cognitive ability, students' management and control of their efforts on academic tasks, even when there is distraction such as noise making, they still maintain their focus which enables them to perform better (Barak, 2009). The self-regulated learning strategy is one of two intervention strategies applied in this study because it enhances cognitive engagement in learning, and this may result in higher level of achievement in Basic science.

This study will utilize behavioural theory perspective on self-regulated learning which is derived largely from the work of Skinner (Mace, 2005). Researcher working within the framework of his operant conditioning theory apply operant principles in diverse settings for example, clinical academic with adults and children with the aim of reducing dysfunctional behaviours and replacing them with more adaptive behaviour (Zimmerman, 2010). Students selfregulate their behaviour by initially deciding which behaviours they will adopt. They can establish discriminative stimuli for their occurrence, provide self-instruction as needed, and monitor their achievement to determine whether the desired behaviour occurs.

The second intervention strategy applied in this study is the Demonstration method; a "how-to-do-it" way of acquiring skills in science. In demonstration methods, teachers identify 
and indicate when materials to be used in teaching are dangerous or when the materials for teaching are in adequate. During demonstration the students listen, observe and watch keenly and participate less. In this method, the teaching of Basic Science appears to be reduced to a descriptive exercise through the use of conventional demonstration with minimal activities. However, this study posits the view that making students aware of their role in self-regulating their learning (cognitive behaviours) could facilitate effect learning while a teacher acts as a mediator or a facilitator. Samuelson (2010) observed that most teachers emphasized demonstration method of teaching science rather than activity-based strategies such as peer collaboration, constructivism and self-regulated aspect of teaching science subjects.

Gender is another relevant issue in the learning of Science and Technology, since the social expectations that prescribe how students think, act, and feel differ across gender. In Nigeria, as in many other countries, Science and Technology are usually viewed as male dominant subjects (Ogunkunle, 2009). Girls opt for careers in humanities and social science related fields. Gender differences in science achievement has been a major concern in science education and science educators seek to provide avenues for achieving gender equity for sustainable development.

Performance in the science at both upper basic and senior secondary school levels of education in Nigeria varies across gender. Female students are reported to be more scared of science subjects and as a result, fewer girls than boys who take the science subjects at the Senior School (SS) level performed poorer at the SSCE than their male counter-parts (Okeke, 2008). Aigbomian's (2006) study comparing performance of boys and girls in Nigeria in basic science shows that boys perform better than girls in science and technology. Ogunkunle (2009) observed that boys perform better than girls in science, technology and mathematics in which basic science is inclusive in measures of problem-solving skills at the complex cognitive level. The author attributed the low achievement of girls to spatial ability and other cognitive disadvantages. On the other hand, Hydea and Mertzb (2009) in their large-scale study in the US observed that girls performed better than their male counter-parts in science subjects.

The existing gap that needs to be filled by the researcher, which this study aims to achieve is the fact that the record of use of SRL in the study area is scarce and that in Basic Science and Technology, strategies that are more activity oriented have not been given attention. Thus, the study examined the effect of Self-Regulated Learning strategy on students' achievement in Makurdi Local Government Area of Benue State Nigeria. 


\section{Purpose of the Study}

The purpose of this study was to ascertain the effect of self-regulated learning strategy in facilitating achievement in Basic Science among Junior Secondary School students. The specific objectives of the study subsumed under this purpose include to;

i. Determine the effect of Self-regulated Learning Strategy on students' achievement in Basic science in Makurdi Local Government Area

ii. Determine the effect of Self-regulated Learning Strategy on the achievement scores of male and female students in basic science in Makurdi Local Government Area

\section{Research Questions}

The following are the research questions that guided the study.

i. What is the mean achievement scores of students taught basic science using Selfregulated learning strategy compared to those taught using Demonstration method?

ii. What is the difference in the mean achievement scores between male and female students taught basic science using self-regulated learning strategy?

\section{Hypotheses}

The following hypotheses were formulated and tested at 0.05 level of significance.

Ho1: There is no significant difference between the mean achievement scores of students taught basic science using Self-regulated Learning Strategy and those taught using the demonstration method.

Ho2: There is no significant difference between the mean achievement of male and female students taught basic science using Self-regulated Learning Strategy.

\section{Research Method}

The study employs the quasi - experimental design. The two learning conditions are SelfRegulated Learning verses(vs) Control (Demonstration method (DM)) X 2 (time: pre-test Vs post-test) mixed factorial design was used. The choice of this design was based on the reality that this study would be working with intact classes and that it was not feasible to adopt true experimental design where the randomization of subjects to experimental and control groups would necessarily distort the academic programmes of the schools involved.

The total population of this study consisted of 7,034 upper basic two students in 52 government grant-aided secondary schools in Makurdi local government area of Benue State. 
The sample for this study consisted of 128 students from six co-educational secondary school taken from the population of 638 students of grant aided schools, using stratified sampling techniques to select only co-educational schools and then simple random sampling to select six schools by hat and draw method. Only co-educational schools were used, since gender is a moderator variable.

The instrument used in this study to collect relevant data was Basic Science Achievement Test (BSAT). The researchers developed two forms of BSAT, pre-test, post-test Basic Science Achievement Test (BSAT) for upper basic 2 (UB2). The instrument is made up of two parts; section $\mathrm{A}$ is the demographic information while section $\mathrm{B}$ consists of multiple-choice test made up of initial 45 items and later reduced to 40 items after validation with four options (a- d) for the students to answer all.

The BSAT was administered twice, before (pre) and after (post) the experiment. The preBSAT was used to ascertain the level of basic science academic achievement levels that the students were at before the treatment. The post-BSAT was used to determine the extent of students Basic Science achievement after the treatment. Descriptive statistics of means and standard deviation were used to answer all research questions and inferential statistics of analysis of Co-variance (ANCOVA) was used to test all the hypothesis at 0.05 significance level. The difference between the two forms of BSAT was in the arrangement of item options and reshuffled serial numbering only. The topics chosen were from basic science book 2 syllabuses/ curriculum.

a. Metabolism of food in human body (digestive system)

b. Drug and drug abuse

c. Elements, compounds, and mixtures

d. Disease vectors

The items of BSAT are based on the upper Basic Science curriculum, and most of the questions were obtained from the past JSCE/BECE question papers. Consideration was given to the behavioural objectives of the content taught in the lesson plan as they serve as a guide on determining the number of topics for each of the units studied.

\section{Development of Basic Science Achievement Test (BSAT):}

The BSAT consisted of 40 multiple choice objective questions with options (a-d), the items were selected to cover lower and higher order cognitive levels of Blooms' taxonomy of educational objectives. A table of specification was used to determine the number of items in different 
Effect of Self-Regulated Learning Strategy on students' achievement in Basic Science in Makurdi Local Government, Benue State, Nigeria.

cognitive ability levels and topics. In the table of specification for Basic Science Achievement Test (BSAT), the reflection of questions were seen more at the lower order cognitive level than higher order cognitive level because the study is based on upper basic level(upper basic 2 ) in Basic Science Achievement Test (BSAT). This is in line with Piagets' theory of cognitive development. The learners' level of cognitive ability at this stage is lower compared to what is expected of the senior secondary students (of age 13 years and above) as categorised by Piaget.

In scoring the students on the BSAT, each correct answer was rewarded a score of one point, while every wrong answer was scored zero. The range of score for each respondent was zero and maximum of forty (40) points. Two sets of lesson plans were developed by the researcher and used in teaching both the experimental and the control groups.

All the students in the experimental group received training on self-regulated learning strategy. After pre-test, they received training for two periods (of 40 minutes each) before taking part in the treatment, except the control group. The process involved think-aloud protocols. The teacher guided the learners to effectively deploy think-aloud practices; reflecting, questioning response, jot down points for review later and seeking for better alternative.

Firstly, for Self-regulated Learning Strategy (SRLS) after pre-test, text materials were presented to the students, followed by instructions on how to go about the learning task. This was followed by guidelines for self-regulated learning:

i. Planning (about what learning materials to learn)

ii. Goal settings (how to achieve the learning task)

iii. Strategy implementation (SQ4R- Survey) students first survey text materials by reading the chapters, headings, and sub-headings, after which they develop Questions in their minds. By this and through think-aloud, their doubts, query and confusion are expressed for attention. After Reading, students try to recall what they have read, then they review the text materials and reflect on them.

iv. Summarizing (salient points)

v. Self-monitoring (monitoring one's progress)

vi. Self-evaluation (passing Judgment)

vii. Teacher acts as a guide. (Note that, learning without a teacher in a classroom context/situation is regarded as ineffective). There must be a teacher to guide, direct and instruct what the students must do. The application of learner centred non- 
conventional methods does not mean that the students will learn without the teacher guiding them.

Secondly, conventional demonstration method is used in basic science teaching; a method which involves carrying out activities to illustrate concepts or ideas. Demonstration can be carried out by teacher alone, teacher with a student/pupil, and or an invited guest. For the purpose of this research, demonstration method was used with the control group (CG) to compare with the non-conventional methods like the SRLS. Demonstration translates an abstract concept to real life subject. It develops student's skills of observation, recording, measuring, and creates a high degree of attention, concentration and interest in students. However, students' participation in the lesson is less, the method is partly a teacher centred approach, and the students only watch, observe keenly and jot down points. A research assistant, who was trained to teach basic science using demonstration method as a control followed the lesson prepared for the group by the researchers.

\section{Validation and Reliability of Instrument}

Both face and content validations were done in this study. The Basic Science Achievement Test (BSAT) and the lesson plans for the two strategies were validated by three experts in science education (two of them are Professors in Science Education and the third a Senior Lecturer in Science Education). For BSAT the experts' pieces of advice were sought in terms of scope of coverage, content, relevance, ambiguity and vagueness of expression. The experts also checked, whether the BSAT answers were correct or not. The correction and suggestions made by these experts were used to review the BSAT items to obtain the degree of accuracy to measure what it's supposed to measure.

Reliability is the consistency with which an instrument measures what it is supposed to measure (Emaikwu, 2013). To ensure the reliability of this study, a pilot study was conducted using 30 upper basic 2 (UB2) students from ECWA Secondary School, North Bank, Makurdi. The school was not part of the schools selected for the main study. Two research assistants were trained to handle the experimental groups for six weeks based on the lesson plans. The aim of conducting the pilot study was to determine the reliability coefficient of the research instrument, to determine the appropriate length of time of the test, and to determine the effectiveness of the research procedure. The BSAT was administered to two groups; before the treatment to ascertain their entry behaviour and after exposure to SRL while the control group was taught using conventional demonstrational methods for six weeks respectively. The students were 
Effect of Self-Regulated Learning Strategy on students' achievement in Basic Science in Makurdi Local Government, Benue State, Nigeria.

assessed using BSAT after treatment. The pre-test and post-test items were the same in content but different in organisation and were scored out of 40 points.

The scores obtained were used to calculate the reliability coefficient of the instrument using Kuder-Richardson 20 formula (KR-20) to obtain 0.99.The KR-20 was used to establish the reliability of BSAT because of the correct or wrong answers scoring nature of the multiplechoice test instrument used. This shows that the instrument can measure the objectives of the study (Emaikwu, 2013).

The result was further subjected to psychometric analysis. This was an attempt to determine the quality of a test in terms of how difficult the test items may be and how discriminating the distracters are. These were calculated by computing the difficulty, discrimination and distracter indices of 45 test items administered to the students.

\section{Results}

Data analysis and interpretation based on research questions and hypotheses.

\section{Research Question 1}

What is the effect of Self-regulated Learning Strategy and Demonstration method on students' achievement in basic science in Upper basic 2 in Makurdi Local Government?

Table 1: Mean and Standard Deviation of Students Scores in Self-regulated Learning and Demonstration Strategy Classes

\begin{tabular}{|c|c|c|c|c|}
\hline \multicolumn{2}{|l|}{ Group } & \multicolumn{2}{|c|}{ Pre-BSAT Post-BSAT } & \multirow{2}{*}{$\begin{array}{l}\text { Mean Gain } \\
3.22\end{array}$} \\
\hline Self-Regulated Learning & Strategy Mean & 18.54 & 21.76 & \\
\hline (SRLS) & $\mathrm{N}$ & 41 & 41 & \\
\hline & Std. Deviation & 4.42 & 5.04 & \\
\hline \multirow[t]{3}{*}{ Demonstration method (DM) } & Mean & 12.37 & 16.88 & 4.51 \\
\hline & $\mathrm{N}$ & 41 & 41 & \\
\hline & Std. Deviation & 3.94 & 4.66 & \\
\hline Mean difference & & 6.17 & 4.88 & 1.29 \\
\hline
\end{tabular}


compared to those in Self-regulated class. By implication, Demonstration method facilitated achievement in Basic science compared to Self-regulated Strategy that was used as experimental class. Therefore, Demonstration method enhanced students' achievement in Basic Science better than Self-regulated Strategy.

\section{Research Question 2}

What is the difference in the mean achievement scores between male and female students taught basic science using self-regulated strategy?

Table2: Mean and Standard Deviation of Male and Female Students' Score in Self-regulated Learning Class

\begin{tabular}{lllll}
\hline Gender & \multicolumn{3}{l}{ Pre-BSAT SRLS Post-BSAT SRLS } & Mean Gain \\
\hline Male & Mean & 18.37 & 21.74 & 3.37 \\
& $\mathrm{~N}$ & 27 & 27 & \\
& Std. Deviation & 3.75 & 4.35 & 2.94 \\
Female & Mean & 18.85 & 21.79 & \\
& $\mathrm{~N}$ & 14 & 14 & \\
& Std. Deviation & 5.63 & 6.36 & 0.43 \\
\hline
\end{tabular}

Table 2 reveals a mean gain of 3.37 for the male students in Self-regulated Strategy class while the females in the same class had 2.94 with a mean difference of 0.43 in favour of the male students. This means that the male students received instruction and gained more in Selfregulated class compared with the female students in the same class. Therefore, Self-regulated Strategy facilitated achievement more among the male students in Basic science compared with the female students in the same class. Therefore, Self-regulated Strategy enhanced male students' achievement in Basic Science better than for the female students.

\section{Hypotheses Testing}

HO1: There is no significant difference between the mean achievement scores of students taught basic science using Self-regulated Learning Strategy and those taught using conventional demonstration method. 
Effect of Self-Regulated Learning Strategy on students' achievement in Basic Science in Makurdi Local Government, Benue State, Nigeria.

Table 3: ANCOVA Test of Effects of Self-Regulated Learning Strategy and Demonstration Method on Students' Achievement in Basic Science

\begin{tabular}{llllll}
\hline Source & Type III Sum of Squares & df & Mean Square & F & Sig. \\
\hline Corrected Model & $1651.740^{\mathrm{a}}$ & 4 & 412.935 & 44.038 & .000 \\
Intercept & 148.751 & 1 & 148.751 & 15.864 & .000 \\
PreBSAT & 1146.522 & 1 & 1146.522 & 122.272 & .000 \\
Group & 8.229 & 1 & 8.229 & .878 & .352 \\
Error & 722.016 & 77 & 9.377 & & \\
Total & 32972.000 & 82 & & & \\
Corrected Total & 2373.756 & 81 & & & \\
\hline
\end{tabular}

a. $\mathrm{R}$ Squared $=.696($ Adjusted $\mathrm{R}$ Squared $=.680)$

Table 3; reveals that with $\mathrm{F}_{1,81}=0.88, \mathrm{p}=0.35>0.05$, there is no significant difference between the mean achievement scores of students taught basic science using Self-regulated Learning Strategy and those taught using Demonstration method. This means that the difference in mean between students in Self-regulated strategy class and those in Demonstration method class in Basic Science was not statistically significant. Thus, the null hypothesis is not rejected, and it is therefore concluded that there is no significant difference between the mean achievement scores of students taught basic science using Self-regulated leaning strategy and those taught using Demonstration method.

$\mathbf{H O}_{2}$ : There is no significant difference between the mean achievement scores of male and female students taught basic science using Self-regulated Learning Strategy.

Table 4: ANCOVA Test of Effect of Self-regulated Learning Strategy(SRLS) on Male and Female Students' Achievement in Basic Science

\begin{tabular}{llllll}
\hline Source & Type III Sum of Squares & Df & Mean Square & F & Sig. \\
\hline $\begin{array}{l}\text { Corrected } \\
\text { Model }\end{array}$ & $707.988^{\mathrm{a}}$ & 2 & 353.994 & 43.453 & .000 \\
Intercept & 33.986 & 1 & 33.986 & 4.172 & .048 \\
\hline
\end{tabular}




\begin{tabular}{llllll}
\hline PreBSAT SRLS & 707.969 & 1 & 707.969 & 86.903 & .000 \\
Gender & 1.617 & 1 & 1.617 & .198 & .658 \\
Error & 309.573 & 38 & 8.147 & \\
Total & 20424.000 & 41 & & \\
Corrected Total & 1017.561 & 40 & & \\
\hline
\end{tabular}

a. $\mathrm{R}$ Squared $=.696($ Adjusted $\mathrm{R}$ Squared $=.680)$

It can be seen from Table 4 that with $F_{1,40}=0.20, p=0.66>0.05$, there is no significant difference between the mean achievement scores of male and female students taught basic science using Self-regulated learning strategy. This means that the difference in mean between male and female students in Self-regulated Strategy class in Basic Science was not statistically significant. Therefore, the null hypothesis is not rejected, and it is thus concluded that there is no significant difference between the mean achievement scores of male and female students taught basic science using self-regulated learning strategy.

\section{Discussion of Findings}

Demonstration method enhanced students' achievement in Basic Science better than Selfregulated Learning Strategy. However, there was no significant difference between the mean achievement scores of students taught basic science using Self-regulated Learning Strategy and those taught using demonstration method. The finding of this study disagrees with that of Cromley and Azevedo (2011) who examined the effectiveness of self-regulated learning (SRL) training in facilitating college students' learning with hypermedia in the US in a study titled "Does training on self-regulated learning facilitate students learning with hypermedia? The results of the study revealed that students in the SRL training condition gained a deeper understanding than the control group students when using a hypermedia environment to learn about complex science topics. The researchers concluded that students can be trained to regulate their learning with hypermedia by engaging in several key processes and mechanisms related to SRL, such as planning, monitoring and enactment of effective strategies. The use of SRL along with hypermedia could have created a better and more effective leaning context for Cromley and Azevedo, compared to the sample population in this study that did not seem to have the use of any hypermedia SLR has different validity contexts which include technology and perhaps even the country. Whereas, demonstration method conduces better in countries with poor use of 
educational technologies and where the technology facilitation of SRL with hypermedia might be lacking, demonstration method achieved better results.

The researchers' extensive use of think-aloud practices involving the learners indicate that not only did the learners in the SRL training condition gain a deeper conceptual understanding, but they also more frequently deployed the SRL processes taught them to effectively regulate their learning, and that the use of these processes led generally to increases in students' understanding of the science topic but specifically this did not give them a significant edge over the control group except that it gave the male students a slight but again not significant edge over the female. They (students) regulated their learning by planning, (prior knowledge activation planning), meta-cognitively monitoring their cognitive system (judging their learning, feeling of knowing) and their progress toward goals, deploying effective strategies such as drawing, summarizing, taking notes, reading notes, elaborating knowledge there is surprise in the present study. It was expected that students would regulate their learning by planning, (prior knowledge activation planning), meta-cognitively monitoring their cognitive system (judging their learning, feeling of knowing) and regulate their progress toward goals, deploying effective strategies such as drawing, summarizing, taking notes, reading notes and elaborating knowledge. These were seen in the present study happening practically in the classroom. The active involvement of learners in the classroom must have accounted for the difference. This is contrary to what Cromley and Azevedo (2011) found. However, demonstration method appears to be an effective strategy especially as it is found to be students centred and thus it was intentionally used for the control group to enable us find out strategies that clearly stand out. By implication, self-regulated learning strategy does not stand when compared with demonstration method though from research questions and comparing pre-test with post-test, students gained substantially in SRL class.

Another finding of this study is that Self-regulated Learning Strategy enhanced male students' achievement in Basic Science better than for the female students in the same class. However, there is no significant difference between the mean achievement scores of male and female students taught basic science using self-regulated learning strategy. This was possible because the learners in the SRL training condition gained a deeper conceptual understanding and could have also frequently deployed the SRL processes taught them to effectively regulate their learning, and that the use of these processes could have led to significant increase in students' understanding of the basic science topic among both male and female students. This result agrees with Afolabi and Akinyemi (2009) who found that gender has no significant effect on the 
performance of physics students when taught using Problem Based Learning technique. Also, Oludipe (2012) found that there was no statistically significant difference in the pre-test, post-test and delayed post-test academic achievement means scores of male and female students. Though the present study used the normal upper basic science curriculum which appears to be balanced in content presentation to both males and females and hence there is no significant difference result, the results from Afolabi and Akinyemi's study though in physics is similar because the learners were equally actively engaged and involved in thinking and doing.

Basic science teachers should always employ teaching strategies that allow both male and female students to be actively engaged with the learning materials for meaningful learning to occur.

\section{Conclusion}

The findings of this study haveestablished that demonstration method enhanced students' achievement in basic science better than self-regulated strategy though not statistically significant. However, the study area which is poor in application of technology in teaching and learning and background of the teachers may have accounted for this conclusion as the finding is contrary to previous studies. Further study would be necessary to give the present study a backing. Secondly, SRL strategy proved to be non-discriminatory to both gender and therefore enhanced achievement of both male and female students at near equal level.

\section{References}

Achor, E. E, Imoko, B. I \& Uloko, E.S. (2009).Effect of ethno-mathematics teaching approach on Senior Secondary Students' achievement and retention in locus. Educational Research and Review, 4(8), 385-390. Retrieved on 4/7/2012 from http://www.academicjournal. org/Enn.

Achor, E. E. \& Kalu, R. U. (2014). Incorporating error analysis into the teaching of practical chemistry in senior secondary schools in Makurdi Nigeria: Any effect on achievement? International Journal of Education and Practice, 2(2), 21-34. www.parkinsight.com

Adejoh, M. J. (2012). Improving the quality of integrated science and introductory technology curricular in secondary schools. Nigerian Journal of Teacher Education and Teaching, 4(1), 304-311.

Adejoh, M. J, Amali, A O \& Omaga, J.O (2013) Improving the teaching and learning of basic science and technology through the use of instructional materials and improvisation. In M. O Nder, \& A. OAmali (Eds), Book of reading (22-29). Makurdi: Selfler Academic Press (SAP). 
Effect of Self-Regulated Learning Strategy on students' achievement in Basic Science in Makurdi Local Government, Benue State, Nigeria.

Afolabi, F. \& Akinyemi, O.A. (2009). Constructivist problem based learning technique and the academic achievement of physics students with low ability level in Nigerian Secondary Schools. Eurasian Journal of Physics and Chemistry Education, 1(1): 45-51.

Afolabi, A. O \& Yusuf, M.O. (2010). Effects of computer assisted instruction on secondary school students' performance in biology. The Turkish Journal of Educational Technology, 9(1), 62-69.

Aigbomian, D.O. (2006). Science for All: Implication for the teacher and national development. $14^{\text {th }}$ Inaugural Lectures of the Ambrose Ali University, Ekpoma, Edo State, Nigeria, Benin City: Ambik Press.

Ajagun, G. A (2006). Towards goods performance in school education. Nigeria Journals of Teachers Education and Teaching, 2(1), 117-125

Akalonu, G.C. (2008). Using an instructional approach to break the gender barrier in Science, Technology and Mathematics Education. Owerri: Federal University of Technology Owerri Pub.

Ali, A. (2004). Conducting research in education and the social science. Enugu: Tashiwa Networks Ltd.

Anekwe, M.C(2008). Effectiveness of cooperative learning strategies on student interest in volumetric analysis at sec school. Interdisciplinary Educational journal, 1(2) 39-49.

Azuka, B.F.(2009). Active learning in mathematics classrooms states. UBEB workshop manual for retaining of primary and JSS teachers on the implementation of new UBE curriculum and continuous assessment in schools. Abuja: Marvellous Mike Press Limited.

Davidson, D. (2006). An overview of research on collaborative learning related to Home Economic. Journal of Educational Research 2(22) 362- 365 North Carolina USA.

Emaikwu, S.O (2013). Fundamental of research methods and statistical methods. Makurdi: Selfers Academic Press Limited

Eriba, J.O. (2005). Teachers' competence in science Teaching. New trends in Education, issues and challenges,(pp 38-39), Book of reading. Faculty of Education, Benue State University, Makurdi.

Hydea, J.S \&Mertzb, J.E. (2009). Gender, culture and mathematics performance, Retrieved on $12^{\text {th }}$ January, 2009 from http:11 tetvideo. madisan.com/uw/gender.

Ibe, J. (2008). Effect of instructional material manipulation on breaking gender barriers on achievement of male and female students in Science, Technology, Mathematics Education (STME). Enugu: UNN Pub.

Igboko, K.O. \&Ibeneme, O.T(2011). Effect of collaboration/co-operative work on students' achievement and retention in Introductory Technology. Journal of Education, Federal University of Science and Technology Owerri, 3(1), 11-19. 
Jirgba, M.C. (2008). Attitude of science teachers towards the teaching of integrated science. Unpublished Masters Dissertation, Benue State University, Makurdi.

Keramati, M. (2010). Effect of cooperative learning on academic achievement of physics course. Journal of computers in Maths and science. Technology 29(2), 155-173.

NERDC (2007) Universal Basic Education Commission (UBEC) a nine (9) year basic Education Curriculum Abuja: NERDC press

Nwosu, A.A. (2007). Various teaching methods: An appraisal. In R.N. Amadi, A.D. Iwu\& C.C Onyemerekeya (Eds). Perspective in teaching practice: Owerri: Avan Global Publications

O’Donnel, A.M. (2006). The role of peers and group learning. In P. Alexander \& P Winne (Eds.) Handbook of Educational Psychology (2 ${ }^{\text {nd }}$ ed; pp. 781-801). N.J Mahwah,: Lawrence Erlbaum Associates.

Ogunkule, R.A. (2009). Fostering gender equity in mathematics education for sustainable development. Journal of International Gender Studies, 4, 17-24.

Okebukola, P.A.O. (2005). Teaching and Learning Integrated Science at the JSS Level. The state of art. Nigeria Education Forum, 12(1), 19-33.

Okeke, E.A.C. (2008). Clarification and analysis of gender concepts Focus on research, Reproductive, Health education and gender sensitive classroom. Science teachers association of Nigeria \& STM edu Series 2:5

Okeke, S (2007).Poor teaching Method: The way forward. Onitsha: Nobel Graphite P.32-54

Oludipe, D. I. (2012). Gender difference in Nigerian Junior Secondary Students' academic achievement in Basic Science. Journal of Education and Social Research. 2(1): 93-99.

Poellhuber, B., Chiominne, M. \& Karsenti,F.T. (2008). Effect of peer collaboration and collaborative learning on self-efficacy and persistence in a Learner-Paced Continuous intake model. London: England.

Samba, R. M. O. \& Eriba, J. O (2012). Innovative approaches in teaching different science concepts. Makurdi: Destiny Ventures.

Samuelson, J. (2010). The effect of peer collaboration on children's arithmetic and selfregulated learning skills. Sweden: Linkoping University press.

Winters, F.I. (2009). Peer collaboration: The role of questions and regulatory processes in conceptual-knowledge learning. USA: Maryland.

Wayne, S (2013) The effect of cooperative learning on the academic achievement of social studies unpublished project submitted to the faculty of the evergreen state 
Effect of Self-Regulated Learning Strategy on students' achievement in Basic Science in Makurdi Local Government, Benue State, Nigeria.

college.http//archivies, evergreen.edu/mastersthese/accession8910MIT/StaufferMIT2013. PDFMay/15/2013.

Zimmerman, B.J. (2006). Developing self-fulfilling cycles of academic regulation: an analysis of exemplary instructional models. In D.H. Schunk \& B.J. Zimmerman (Eds.) Self-regulated learning: From teaching to self-reflective practice (pp.1-19). New York: Guilford Press.

Zimmerman, B.J. (2008). Investigating self-regulation and motivation: historical background, methodological developments, and future prospects. American Educational Research Journal, 45(1), 166-183. 